\title{
PENGARUH MODEL ATI BERBANTUAN MEDIA AUDIO VISUAL TERHADAP HASIL BELAJAR IPA SISWA KELAS V SD
}

\author{
I Km. Merdana Ariasa ${ }^{1}$, Nym. Kusmariyatni ${ }^{2}$ Ndara Tanggu Renda ${ }^{3}$ \\ 1,2,3 Jurusan Pendidikan Guru Sekolah Dasar, Universitas Pendidikan Ganesha, Singaraja, Indonesia \\ e-mail: ${ }^{1}$ sumerdana123@gmail.com, ${ }^{2}$ nyoman.kusmariyatni@undiksha.ac.id, \\ 3ndaratanggu.renda@undiksha.ac.id
}

\begin{abstract}
Abstrak
Jenis penelitian ini adalah penelitian eksperimen semu dengan rancangan post test only control group design. Penelitian ini mencoba mengeksperimenkan model pembelajaran Aptitude Treatment Interaction ( $A T I$ ) berbantuan media audio visual yang bertujuan untuk mengetahui pengaruhnya terhadap hasil belajar IPA pada siswa kelas V SD di Gugus IV Cempaka Putih Kecamatan Kubutambahan. Populasi penelitian ini adalah seluruh kelas V SD di Gugus IV Cempaka Putih, yang berjumlah 168 siswa. Sampel penelitian ini yaitu kelas V SD Negeri 2 dan 3 Bulian dengan jumlah siswa masing-masing 25 dan 27 siswa, yang ditentukan dengan teknik random sampling. Data dianalisis dengan statistik deskriptif dan Independent Sample t-test. Hasil penelitian menunjukkan bahwa nilai $t_{\text {hitung }}$ sebesar 2.025 dan $t_{\text {tab }}$ sebesar 2,00. Artinya, terdapat pengaruh yang signifikan hasil belajar IPA antara kelompok siswa yang dibelajarkan dengan model pembelajaran ATI berbantuan media audio visual dan kelompok siswa yang dibelajarkan dengan model pembelajaran bukan $A T I$ berbantuan media audio visual.
\end{abstract}

Kata kunci: $A T I$, audio visual, hasil belajar IPA

Abstract

This study used quasi experiment research through post test which only used control group design. This study tried to experiment Aptitude Treatment Interaction (ATI) model assisted audio visual media aimed to know the effect on science learning outcomes in grade $V$ elementary students in Group IV Cempaka Putih Kecamatan Kubutambahan. The population of this study were the entire students of grade $V$ in group IV Cempaka Putih, which amount to 168 students. The sample of this research were class V SDN 2 and 3 Bulian with the number of each students were 25 and 2, which was determined by random sampling technique. The data were analyzed by descriptive statistic and Independent Sample t-test. The results showed that the value of $t$ count of 2.025 and ttab of 2.00. It meant that there was a significant effect of science learning outcomes between groups of students who were taught by ATI model assisted audio visual media and groups of students who were taught by non-ATI assisted by audio visual media.

Keywords : ATI, audio visual, science learning outcomes

\section{Pendahuluan}

Globalisasi yang penuh dengan persaingan, sumber daya manusia (SDM) menjadi suatu hal yang sangat penting untuk dikembangkan. Dalam usaha pengembangan sumber daya manusia tersebut, terdapat berbagai faktor yang sangat berpengaruh. Salah satunya adalah pendidikan yang berkualitas sebagai kunci untuk kemajuan dan perkembangan SDM. Melalui pendidikan, manusia dapat mewujudkan semua potensi dirinya baik sebagai pribadi maupun sebagai warga masyarakat. Menurut UU No. 20 th 2003 tentang sistem pendidikan nasional pasal 1 ayat 1 dinyatakan bahwa, pendidikan adalah usaha sadar dan terencana untuk mewujudkan suasana belajar dan proses pembelajaran agar peserta didik secara aktif mengembangkan potensi dirinya untuk memiliki kekuatan spiritual keagamaan, pengendalian diri, kepribadian, kecerdasan, akhlak mulia, serta keterampilan yang diperlukan dirinya, masyarakat, bangsa dan negara.

Sesuai dengan isi undang-undang tersebut, maka pendidikan merupakan salah satu kebutuhan pokok bagi setiap orang yang mencakup semua aspek kehidupan manusia dalam upaya penyiapan SDM yang bermutu. Penyiapan SDM yang bermutu tidaklah mudah 
dilakukan, diperlukan adanya pendidikan formal yaitu proses pembelajaran agar pendidikan dapat berjalan dengan baik sesuai dengan tujuannya. Sulastriningsih (2012:2) dinyatakan bahwa proses pembelajaran yang bermutu akan menghasilkan output sumber daya manusia yang lebih bermutu. Unsur-unsur pendidikan berkualitas akan mendukung perkembangan pendidikan. Unsur-unsur dalam pelaksanaan pendidikan diantaranya adalah guru, siswa, sarana dan prasarana pendidikan maupun kebijakan yang telah ditetapkan oleh pemerintah dalam bidang pendidikan.

Pemerintah telah berupaya melakukan pembaharuan di bidang pendidikan seperti perubahan dalam bidang menajemen pendidikan, bidang kurikulum, proses pembelajaran, dan bidang tenaga pendidikan demi menyiapkan sumber daya manusia yang berkualitas. Dengan adanya perubahan di bidang pendidikan, maka akan berimplikasi pada perubahan pemikiran dan komitmen bagi guru untuk pengembangan diri. Perubahan pemikiran tersebut mengacu kepada perubahan paradigma dari bagaimana mengajar ke arah bagaimana belajar dan bagaimana menstimulasi pembelajaran yang lebih banyak melibatkan siswa dengan memperhatikan kebutuhan siswa, sehingga proses pembelajaran akan lebih bermakana dan akan mampu membuat siswa aktif dalam proses pembelajaran.

Dalam melaksanakan pembelajaran khususnya di SD diterangkan pada Pasal 37 (1) UU No. 20 Tahun 2003 Sisdiknas tersebut salah satunya adalah mata pelajaran Ilmu Pengetahuan Alam (IPA). Menurut Trianto (2012:136) dinyatakan bahwa, IPA adalah suatu kumpulan teori yang sistematis, penerapannya secara umum terbatas pada gejala-gejala alam, lahir dan berkembang melalui metode ilmiah seperti observasi dan eksperimen serta dituntut sikap ilmiah seperti rasa ingin tahu, terbuka, jujur dan sebagainya.

Pembelajaran IPA di SD diharapkan meletakkan dasar kecerdasan, pengetahuan, kepribadian, akhlak mulia, serta keterampilan untuk hidup mandiri dan mengikuti pendidikan lebih lanjut (BSNP, 2006). Proses pembelajaran IPA tidak menuntut siswa sekedar menghafal sejumlah konsep dan prinsip IPA yang dibelajarkan.

Ada beberapa tujuan pelaksanaan pembelajaran IPA di SD salah satunya mengembangkan rasa ingin tahu, sikap positif, dan kesadaran tentang hubungan IPA (BNSP, 2006). Untuk mencapai tujuan pembelajaran IPA di sekolah dasar ditentukan oleh berbagai faktor. Salah satu faktor yang berpengaruh adalah keikutsertaan secara aktif siswa dalam pembelajaran. Keaktifan siswa ini akan dapat menciptakan multiple kompetensi dalam diri siswa. Semakin banyak persentase keterlibatan siswa dalam pembelajaran, suasana belajar akan terkesan semakin menarik. Pembelajaran yang menarik akan memberikan peluang kepada siswa untuk menuangkan ide-ide kreatifnya. Di samping itu, pembelajaran yang menarik juga akan membantu siswa untuk meningkatkan pemahamannya terhadap materi yang dipelajari dalam proses pembelajaran. Oleh karena itu pembelajaran IPA di SD menekankan pada pemberian pengalaman belajar secara langsung melalui penggunaan dan pengembangan keterampilan proses dan sikap ilmiah (Jayanto, 2013). Dengan demikian kualitas dari hasil belajar IPA akan meningkat, namun kenyataannya belum mencapai hasil belajar yang diharapkan.

Berdasarkan kenyataan ketika dilakukan wawancara dengan guru kelas V SD di Gugus IV Cempaka Putih Kecamatan Kubutambahan pada tanggal 23 Nopember 2017, diperoleh hasil yaitu 1) siswa kurang aktif dalam proses pembelajaran, 2) siswa sering bercanda saat proses pembelajaran berlangsung, 3) perbedaan kemampuan kognitif dari siswa sehingga pembelajaran tidak berlangsung sesuai dengan yang diharapkan.

Setelah dilakukan wawancara, dilanjutkan dengan kegiatan observasi proses pembelajaran IPA kelas V SD di Gugus IV Cempaka Putih Kecamatan Kubutambahan pada tanggal 24-27 Nopember 2017. Pertama, guru mengajar dengan ceramah yang menimbulkan kejenuhan sehingga materi IPA sulit dipahami. Proses pembelajaran IPA cenderung berpusat pada guru, sehingga pembelajaran terjadi hanya satu arah. Siswa hanya mendengarkan yang dijelaskan oleh guru. Kedua, guru jarang mengarahkan siswa untuk melakukan percobaan/eksperimen. Guru hanya memberikan teori dalam proses pembelajaran yang berlangsung. Hal ini disebabkan karena kurangnya fasilitas yang dimiliki oleh sekolah. Padahal sebenarnya untuk memahami IPA tidak cukup dengan teori. Ketiga, guru tidak banyak mengenal dan menggunakan model-model pembelajaran yang inovatif 
yang mampu digunakan dalam pembelajaran di kelas. Kebanyakan guru hanya mengenal model ceramah, diskusi, dan tanya jawab padahal masih banyak model-model pembelajaran inovatif lainnya yang bisa digunakan guru dalam proses pembelajaran.

Melengkapi hasil wawancara dan observasi, maka dilaksanakan pencatatan dokumen terhadap hasil belajar IPA kelas V SD di Gugus IV Cempaka Putih Kecamatan Kubutambahan. Berdasarkan hasil pencatatan dokumen diperoleh nilai Ulangan Akhir Semester (UAS) yang masih di bawah rata-rata KKM. Diketahui rata-rata hasil tes IPA di SDN 2 Bulian adalah 69,32, di SDN 3 Bulian adalah 65, di SDN 1 Depeha adalah 57, di SDN 2 Depeha adalah 63,06, di SDN 3 Depeha adalah 66,76, di SDN 4 Depeha adalah 66,22

Berdasarkan nilai rata-rata UAS IPA siswa kelas V SD di Gugus IV Cempaka Putih Kecamatan Kubutambahan berkisar antara 57-69,32 dengan kategori kurang (Koyan, 2011:119). Hal ini merupakan suatu masalah yang harus diatasi agar hasil belajar siswa menjadi lebih baik. Maka dari itu perlu sebuah inovasi pembelajaran untuk meningkatkan hasil belajar IPA. Inovasi pembelajaran yang tepat untuk mengatasi masalah di atas perlu diterapkannya berbagai jenis pendekatan, strategi, dan model pembelajaran.

Model pembelajaran yang dapat digunakan, adalah model pembelajaran Aptitude Treatment Interaction (ATI). Model ini memberikan kesempatan kepada guru untuk mengembangkan kinerja profesionalnya dengan menggunakan bermacam-macam metode mengajar pada tiga bentuk perlakuan (treatment). Menurut Nurdin (dalam Putra, 2013:3) model pembelajaran Aptitude Treatment Interaction (ATI) dapat diartikan sebagai "suatu konsep atau model yang berisikan sejumlah strategi pembelajaran (treatment) yang efektif digunakan untuk siswa tertentu sesuai dengan perbedaan kemampuan (aptitude)". Terlebih lagi jika model pembelajaran ini dipadukan dengan media audio visual maka pembelajaran akan terkesan semakin menarik. Media audio visual digunakan sebagai perantara untuk menyampaikan materi kepada siswa.

Berdasarkan uraian di atas, maka penelitian ini akan difokuskan pada Pengaruh Model Pembelajaran Aptitude Treatment Interaction (ATI) Berbantuan Media Audio Visual Terhadap Hasil Belajar IPA Siswa Kelas V SD Semester II di Gugus IV Cempaka Putih Kecamatan Kubutambahan Kabupaten Buleleng Tahun Pelajaran 2017/2018.

\section{Metode}

Penelitian ini merupakan jenis penelitian eksperimen semu (quasi experiment), karena tidak semua variabel dapat dikendalikan secara ketat. Tempat pelaksanaan penelitian ini adalah SD Gugus IV Cempaka Putih Kecamatan Kubutambahan Kabupaten Buleleng. Waktu penelitian ini pada semester genap tahun pelajaran 2017/2018. Populasi dalam penelitian ini adalah semua siswa kelas V di SD Gugus IV Cempaka Putih yang berjumlah 6 sekolah dasar. Jumlah seluruh anggota populasi adalah 168 siswa. Banyaknya populasi dan sebarannya dapat dilihat pada tabel 1. berikut.

Tabel 1.Populasi Penelitian

\begin{tabular}{ccc}
\hline No. & Nama SD & $\begin{array}{c}\text { Jumlah Siswa } \\
\text { (Orang) }\end{array}$ \\
\hline 1 & SDN 2 Bulian & 25 \\
2 & SDN 3 Bulian & 27 \\
3 & SDN 1 Depeha & 31 \\
4 & SDN 2 Depeha & 33 \\
5 & SDN 3 Depeha & 25 \\
6 & SDN 4 Depeha & 27 \\
& Total Populasi & 168 \\
\hline
\end{tabular}

Pemilihan sampel dalam penelitian ini menggunakan teknik random sampling yaitu pengambilan sampel anggota populasi secara acak tanpa memperhatikan strata yang ada. Tahap pertama dilakukan uji kesetaraan terhadap enam sekolah dasar tersebut. Penyetaraan sampel dihitung berdasarkan nilai Ulangan Akhir Semester IPA kelas V 
Semester I tahun pelajaran 2017/2018. Untuk menghitung kesetaraan kelompok sampel digunakan rumus uji ANAVA. Setelah memperoleh hasil perhitungan uji kesetaraan, selanjutnya keenam SD itu dirandom untuk menentukan kelas eksperimen dan kelas kontrol. Dalam pemilihan kelas eksperimen dan kelas kontrol dilakukan dengan teknik undian. Melalui random sampling tersebut ditetapkan kelas V di SD Negeri 2 Bulian yang berjumlah 25 orang sebagai kelompok eksperimen yang diberi perlakuan berupa Aptitude Treatment Interaction (ATI) Berbantuan Media Audio Visual dan kelas V di SD Negeri 3 Bulian yang berjumlah 27 orang sebagai kelompok kontrol yang diberi perlakuan berupa model pembelajaran bukan Aptitude Treatment Interaction (ATI) Berbantuan Media Audio Visual.

Instrumen pengumpulan data yang digunakan dalam penelitian ini adalah berupa tes objektif. Soal objektif yang digunakan terdiri dari 30 butir soal. Untuk menentukan butir soal instrumen tersebut layak untuk diberikan terhadap kelompok sampel terlebih dahulu dilakukan uji coba. Uji coba tes hasil belajar IPA meliputi: validitas butir tes, reliabilitastes tes, daya beda tes, dan tingkat kesukaran tes. Analisis data dalam penelitian ini dilakukan dalam tiga tahap. Pada tahap pertama dilakukan analisis deskriptif, tahap kedua digunakan analisis uji coba prasyarat untuk pembuktian persyaratan analisis statistik. Sedangkan pada tahap ketiga dilakukan analisis untuk pembuktian hipotesis.

Pengujian terhadap hipotesis penelitian yang telah dirumuskan dilakukan melalui metode statistika, hipotesis pertama dilakukan dengan menggunakan analisis Uji Independent Sample t-test. Sebelum dilakukan uji hipotesis terlebih dahulu dilakukan uji prasyarat analisis yang meliputi uji normalitas sebaran data, uji homogenitas varians. Berdasarkan uji prasyarat analisis data, diperoleh bahwa data hasil belajar IPA siswa kelompok eksperimen dan kontrol adalah normal dan homogen. Setelah diperoleh hasil uji prasyarat analisis data, dilanjutkan dengan pengujian hipotesis penelitian. Pengujian hipotesis tersebut dilakukan menggunakan independent sample t-test (tidak berkorelasi) dengan rumus polled varians. Kriterianya, $\mathrm{H}_{0}$ ditolak jika $\mathrm{t}_{\text {hitung }}>\mathrm{t}_{\text {tabel }}$.

\section{Hasil dan Pembahasan} Hasil

Hasil penelitian ini menunjukkan bahwa terdapat pengaruh yang signifikan hasil belajar IPA antara kelompok siswa yang belajar melalui model pembelajaran Aptitude Treatment Interaction (ATI) Berbantuan Media Audio Visual dan kelompok siswa yang belajar melalui pembelajaran bukan Aptitude Treatment Interaction (ATI) Berbantuan Media Audio Visual pada siswa kelas V SD di Gugus IV Kecamatan Kubutambahan, Kabupaten Buleleng tahun pelajaran 2017/2018. Hal ini dapat dilihat dari hasil belajar IPA yang dicapai oleh siswa. Hasil analisis statistik deskriptif data penelitian ini disajikan pada tabel berikut.

Tabel 2. Analisis Data dengan Statistik Deskriptif

\begin{tabular}{ccc}
\hline Statistik & Kelompok Eksperimen & Kelompok Kontrol \\
\hline Mean & 19,26 & 16,83 \\
Median & 19,82 & 16,66 \\
Modus & 21,1 & 16,26 \\
Standar Deviasi & 4,69 & 3,99 \\
Varians & 21,99 & 15,89 \\
\hline
\end{tabular}

Berdasarkan data pada tabel di atas, data hasil belajar IPA kelompok eksperimen disajikan dalam bentuk kurva polygon, seperti gambar 1 berikut ini. 


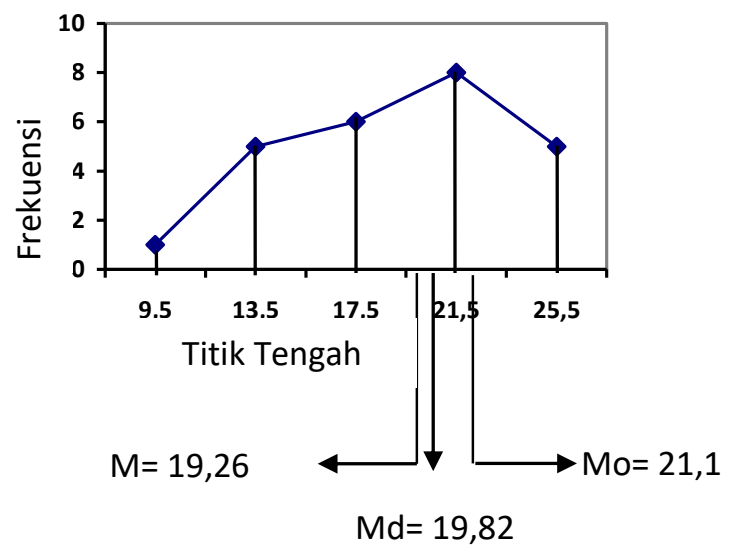

Gambar 1.Kurva Poligon Data Hasil Belajar Kelompok Eksperimen

Berdasarkan kurva poligon data hasil belajar kelompok eksperimen di atas, dapat diketahui bahwa modus lebih besar dari median dan median lebih besar dari mean $(\mathrm{Mo}>\mathrm{Md}>\mathrm{M})$. Dengan kata lain, kurva di atas adalah kurva juling negatif. Artinya, sebagian besar skor cenderung tinggi. Kecenderungan skor ini dapat dibuktikan dengan melihat frekuensi relatif pada tabel distribusi frekuensi. Frekuensi relatif skor yang berada di atas rata-rata lebih besar dibandingkan frekuensi relatif skor yang berada di bawah rata-rata. Sedangkan data hasil belajar siswa kelas kontrol disajikan pada gambar 2 berikut ini.

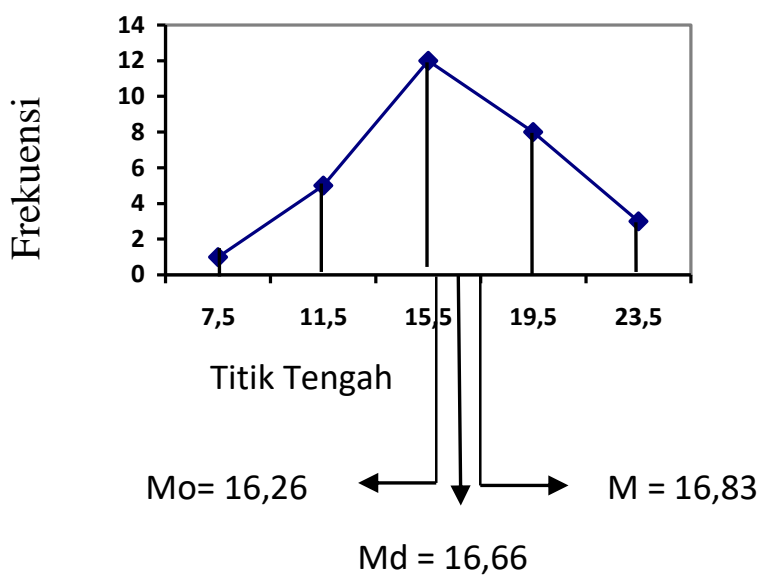

Gambar 2. Kurva Poligon Data Hasil Belajar Kelompok Kontrol

Berdasarkan kurva poligon data hasil belajar kelompok kontrol di atas, dapat diketahui bahwa modus lebih kecil dari median dan median lebih kecil dari mean $(\mathrm{Mo}<\mathrm{Md}<\mathrm{M})$. Dengan kata lain, kurva di atas adalah kurva juling positif. Artinya, sebagian besar skor cenderung rendah. Kecenderungan skor ini dapat dibuktikan dengan melihat frekuensi relatif pada tabel distribusi frekuensi. Frekuensi relatif skor yang berada di atas rata-rata lebih kecil dibandingkan frekuensi relatif skor yang berada di bawah rata-rata.

Setelah melakukan analisis statistik deskriptif, selanjutnya dilakukan uji prasyarat untuk menguji hipotesis. Uji prasyarat yang dilakukan adalah uji normalitas dan homogenitas.

Uji normalitas data dilakukan terhadap data hasil belajar IPA kelompok eksperimen dan kontrol. Berdasarkan analisis data yang dilakukan, dapat disajikan hasil uji normalitas sebaran data hasil belajar IPA kelompok eksperimen dan kontrol pada Tabel 3. di bawah ini. 
Tabel 3. Hasil Uji Normalitas Sebaran Data Hasil Belajar IPA

\begin{tabular}{ccccc}
\hline No & $\begin{array}{c}\text { Kelompok Data Hasil } \\
\text { Belajar }\end{array}$ & $\chi^{2}$ & $\begin{array}{c}\text { Nilai Kritis dengan Taraf } \\
\text { Signifikansi 5\% }\end{array}$ & Status \\
\hline 1 & Eksperimen & 1,566 & 5,99 & Normal \\
2 & Kontrol & 2,12 & 5,99 & Normal \\
\hline
\end{tabular}

Berdasarkan hasil perhitungan dengan menggunakan rumus Chi Squre, diperoleh $\chi^{2}{ }_{\text {hitung }}$ skor hasil belajar IPA siswa kelompok eksperimen adalah 1,566, sedangkan $\chi^{2}$ tabel dengan taraf signifikansi $5 \%$ dan $\mathrm{dk}=2$ adalah 5,99. Hal ini berarti, $\chi^{2}{ }_{\text {hitung }}$ skor hasil belajar IPA siswa kelompok eksperimen lebih kecil dari $\chi_{\text {tabel }}^{2}\left(\chi^{2}{ }_{\text {hitung }}<\chi^{2}\right.$ tabel $)$, sehingga data hasil belajar IPA siswa kelompok eksperimen berdistribusi normal. Selanjutnya, $\chi^{2}$ hitung skor hasil belajar IPA siswa kelompok kontrol adalah 2,12 dan $\chi_{\text {tabel }}^{2}$ dengan taraf signifikansi $5 \%$ dan $\mathrm{dk}=2$ adalah 5,99. Hal ini berarti, $\chi^{2}$ hitung data hasil belajar kelompok kontrol lebih kecil dari $\chi_{\text {tabel }}^{2}\left(\chi_{\text {hitung }}^{2}<\chi_{\text {tabel }}^{2}\right)$, sehingga data hasil belajar IPA siswa kelompok kontrol berdistribusi normal.

Selanjutnya, uji homogenitas dilakukan terhadap varians pasangan antara kelompok eksperimen dan kelompok kontrol. Hasil uji homogenitas varians antara kelompok eksperimen dan kelompok kontrol disajikan pada tabel berikut ini.

Tabel 4. Hasil Uji Homogenitas Kelompok Eksperimen dan Kontrol

\begin{tabular}{cccc}
\hline Sumber Data & $\mathbf{F}_{\text {hit }}$ & $\begin{array}{c}\mathbf{F}_{\text {tab }} \text { dengan Taraf } \\
\text { Signifikansi 5\% }\end{array}$ & Status \\
\hline $\begin{array}{c}\text { Eksperimen } \\
\text { Kontrol }\end{array}$ & 0,322 & 3,841 & Homogen \\
\hline
\end{tabular}

Berdasarkan tabel di atas, diketahui $F_{\text {hitung }}$ skor hasil belajar IPA siswa kelompok eksperimen dan kontrol adalah 1,38, sedangkan $\mathrm{F}_{\text {tabel }}$ dengan $\mathrm{dk}_{\text {pembilang }}=26$ dan $\mathrm{dk}_{\text {penyebut }}=$ 24 pada taraf signifikansi $5 \%$ adalah 3,841 . Hal ini berarti, varians data hasil belajar IPA siswa kelompok eksperimen dan kontrol adalah homogen.

Berdasarkan uji prasyarat analisis data, diperoleh bahwa data hasil post-test kelompok eksperimen dan kelompok kontrol adalah normal dan homogen. Setelah diperoleh hasil dari uji prasyarat analisis data, dilanjutkan dengan pengujian hipotesis penelitian $\left(\mathrm{H}_{1}\right)$ dan hipotesis nol $\left(\mathrm{H}_{0}\right)$. Pengujian hipotesis tersebut dilakukan dengan menggunakan uji-t dengan rumus polled varians dengan kriteria $H_{0}$ tolak jika $t_{\text {hit }}>t_{\text {tab }}$ dan $H_{0}$ terima jika $t_{\text {hit }}<t_{\text {tab }}$. Rangkuman hasil perhitungan uji-t antara kelompok eksperimen dan kelompok kontrol disajikan pada tabel 5 di berikut ini.

Tabel 5. Ringkasan Hasil Uji Hipotesis

\begin{tabular}{lcccccc}
\hline \multicolumn{1}{c}{ Kelompok Data Hasil belajar IPA } & Varians & $\mathbf{N}$ & $\mathbf{D k}$ & $\mathbf{t}_{\text {hitung }}$ & $\mathbf{t}_{\text {tabel }}$ & Kesimpulan \\
\hline Kelompok Eksperimen & 21,1 & 25 & \multirow{2}{*}{50} & 2,025 & \multirow{2}{*}{2,0} & $\mathbf{t}_{\text {hitung }}>\mathrm{t}_{\text {tabel }} \mathrm{H}_{0}$ \\
Kelompok Kontrol & 15,89 & 27 & & & & \\
\hline
\end{tabular}

Berdasarkan tabel di atas, tampak bahwa $t_{\text {hitung }}$ sebesar 2,025 , sedangkan, $t_{\text {tabel }}$ dengan $\mathrm{dk}=50$ pada taraf signifikansi $5 \%$ adalah 2,0 . Hal ini berarti, $t_{\text {hitung }}$ lebih besar dari $t_{\text {tabel }}$ ( $t_{\text {hitung }}>t_{\text {tabel }}$ ) sehingga $H_{0}$ ditolak dan $H_{1}$ diterima. Dengan demikian, dapat diinterpretasikan bahwa terdapat perbedaan yang signifikan pada hasil belajar IPA antara siswa yang belajar dengan model pembelajaran TPS dan siswa yang tidak belajar dengan model pembelajaran ATI berbantuan media audio visual pada siswa kelas V SD di Gugus IV Cempaka Putih Tahun Pelajaran 2017/2018. 


\section{Pembahasan}

Model Pembelajaran ATI berbantuan media audio visual yang digunakan pada kelompok eksperimen dan pada kelompok kontrol yang tidak menggunakan model pembelajaran $A T I$ berbantuan media audio visual dalam penelitian ini menunjukkan pengaruh yang berbeda pada hasil belajar IPA siswa. Hal ini dapat dilihat dari hasil uji-t dan perbedaan rata-rata skor hasil belajar IPA pada kedua kelompok.

Secara deskriptif, hasil belajar IPA siswa kelompok eksperimen lebih tinggi dibandingkan dengan siswa kelompok kontrol. Tinjauan ini didasarkan pada rata-rata skor dan kecenderungan skor hasil belajar IPA yang diperoleh kedua kelompok. Rata-rata skor hasil belajar IPA siswa kelompok eksperimen adalah 19,26 (kategori tinggi), sedangkan ratarata skor hasil belajar IPA siswa kelompok kontrol adalah 16,83 (kategori sedang). Begitu pula yang tampak pada kurva poligon, yang mana sebaran data kelompok ini merupakan juling negatif. Artinya, sebagian besar skor siswa cenderung tinggi. Namun berbeda halnya pada kelompok kontrol, kurva sebaran data merupakan juling positif, yang artinya sebagian besar skor siswa cenderung rendah.

Berdasarkan analisis data menggunakan uji-t, diketahui $t_{\text {hitung }}=2,025$ dan $t_{\text {tabel }}(\mathrm{dk}=$ 50 pada taraf signifikansi $5 \%)=2,0$. Hasil perhitungan tersebut menunjukkan bahwa $t_{\text {hitung }}$ lebih besar dari $t_{\text {tabel }}\left(t_{\text {hitung }}>t_{\text {tabel }}\right)$, sehingga hasil penelitian adalah signifikan. Hal ini berarti, terdapat perbedaan yang signifikan pada hasil belajar IPA antara siswa yang belajar dengan model pembelajaran $A T I$ berbantuan media audio visual dan siswa yang tidak belajar dengan model pembelajaran $A T I$ berbantuan media audio visual. Adanya perbedaan yang signifikan menunjukkan bahwa model pembelajaran $A T I$ berbantuan media audio visual berpengaruh terhadap hasil belajar IPA siswa.

Besarnya pengaruh model pembelajaran ATI dan yang tidak belajar dengan model pembelajaran $A T I$ terhadap hasil belajar dapat dibuktikan dari hasil analisis deskriptif. Hasil analisis deskriptif menunjukkan bahwa rata-rata skor hasil belajar IPA kelompok eksperimen, yaitu 19,26 lebih tinggi daripada kelompok kontrol, yaitu 16,83.

Temuan penelitian yang menunjukkan bahwa Model ATI berbantuan media audio visual berpengaruh terhadap hasil belajar IPA siswa dengan kecenderungan sebagian besar skor siswa tinggi disebabkan oleh beberapa faktor. Faktor pertama, model ATI dapat melatih siswa untuk berpikir sendiri, berdiskusi dengan kelompok, dan menyampaikan hasil diskusinya terkait konsep-konsep IPA yang dipelajari. Kegiatan berpikir akan mengarahkan siswa untuk mengeluarkan kemampuannya dalam memecahkan sebuah permasalahan. Kegiatan diskusi akan menambah keyakinan siswa terhadap hasil pemikirannya. Selanjutnya, kegiatan sharing atau menyampaikan hasil pemikiran kepada teman sekelasnya akan menambah ingatan siswa terkait pemahamannya terhadap konsep. Ketiga kegiatan tersebut dapat memotivasi siswa untuk belajar lebih baik dan menemukan hal-hal yang bermakna dari kegiatan tersebut. Kesempatan tersebut akan memunculkan hasil pemikiran siswa secara murni dan didukung oleh penguatan dari kelompoknya, sehingga berpengaruh terhadap kualitas pemahaman konsep siswa. Hal lain yang terjadi adalah pemahaman yang diperoleh tersebut tidak mudah dilupakan karena proses yang siswa lalui untuk memperolehnya merupakan kegiatan pembelajaran yang bermakna. Temuan tersebut didukung oleh pendapat Nurdin (dalam Putra, 2013:3) model pembelajaran Aptitude Treatment Interaction (ATI) dapat diartikan sebagai "suatu konsep atau model yang berisikan sejumlah strategi pembelajaran (treatment) yang efektif digunakan untuk siswa tertentu sesuai dengan perbedaan kemampuan (aptitude)". Model ini memberikan kesempatan kepada guru untuk mengembangkan kinerja profesionalnya dengan menggunakan bermacam-macam metode mengajar pada tiga bentuk perlakuan (treatment).

Faktor kedua, perpaduan model ATI dengan media audio visual memberikan kesan yang berbeda pada pembelajaran. Media audio visual digunakan sebagai perantara untuk menyampaikan materi kepada siswa. Hal tersebut sesuai dengan pendapat Daryanto (2016:106) media audio visual adalah "segala sesuatu yang memungkinkan sinyal audio dapat dikombinasikan dengan gambar bergerak secara sekuensial" Dengan demikian, media audio visual adalah sesuatu yang dijadikan sebagai perantara untuk menyampaikan pesan atau informasi berupa suara dan gambar yang dapat merangsang pikiran, perasaan, 
perhatian dan kemauan siswa sehingga dapat mendorong terjadinya proses belajar pada diri siswa.

Temuan penelitian tersebut sesuai dengan hasil penelitian sebelumnya yang dilakukan oleh Ni Pt. Irma Partami (2013). Dalam penelitiannya tersebut, dibuktikan bahwa hasil belajar IPS siswa yang mengikuti pembelajaran dengan menggunakan metode Bermain Peran berbantuan media audio visual dapat meningkatkan hasil belajar siswa. Penelitian serupa juga dilakukan oleh I Gd Suryanata (2013). Dalam "Pegaruh Model Pembelajaran Synectics Berbantuan Media Audio Visual Terhadap Hasil Belajar IPS Kelas V SD Gugus II Kecamatan Karangasem". Dalam penelitian tersebut dibuktikan bahwa Media Audio Visual dapat meningkatkan hasil belajar IPA siswa. Penelitian mengenai ATI juga telah dilakukan oleh Oktalia Widyastuti (2013). Keberhasilan penelitian-penelitian tersebut mendukung keberhasilan penelitian tentang pengaruh model pembelajaran $A T I$ berbantuan media audio visual terhadap hasil belajar IPA siswa.

Berdasarkan paparan di atas, maka dapat disimpulkan bahwa model pembelajaran ATI berbantuan media audio visual berpengaruh terhadap hasil belajar IPA siswa.

\section{Simpulan dan Saran}

Berdasarkan hasil penelitian dan pembahasan, dapat disimpulkan bahwa terdapat perbedaan yang signifikan pada hasil belajar IPA antara siswa yang belajar dengan model pembelajaran Aptitude Treatment Interaction ( $A T I$ ) berbantuan media audio visual dan siswa yang tidak belajar dengan model pembelajaran Aptitude Treatment Interaction (ATI) berbantuan media audio visual pada siswa kelas V SD Semester II di Gugus IV Cempaka Putih Kecamatan Kubutambahan Kabupaten Buleleng Tahun Pelajaran 2017/2018. Hal tersebut diperoleh dari hasil penghitungan uji-t, $t_{\text {hit }}$ sebesar 2,025, sedangkan, $t_{\text {tab }}$ (dengan $\mathrm{db}=50$ dan taraf signifikansi 5\%) adalah 2,00. Hal ini berarti, $t_{\text {hit }}$ lebih besar dari $t_{\text {tab }}\left(t_{\text {hit }}>t_{\text {tab }}\right)$, sehingga $\mathrm{H}_{0}$ ditolak dan $\mathrm{H}_{1}$ diterima. Dari rata-rata $(\bar{X})$, diketahui $(\bar{X})$ kelompok eksperimen sebesar 19,26 dan $(\bar{X})$ kelompok kontrol sebesar 16,83. Hal ini berarti $(\bar{X})$ eksperimen > $(\bar{X})$ kontrol. Dengan demikian, model pembelajaran Aptitude Treatment Interaction (ATI) berbantuan media audio visual berpengaruh terhadap hasil belajar IPA pada siswa kelas $\mathrm{V}$ SD Semester II di Gugus IV Cempaka Putih Kecamatan Kubutambahan Kabupaten Buleleng tahun pelajaran $2017 / 2018$.

Saran-saran yang dapat disampaikan berdasarkan penelitian yang telah dilakukan adalah 1) Disarankan kepada siswa di sekolah dasar diharapkan aktif dan bersungguhsungguh mengikuti pembelajaran IPA dengan model pembelajaran ATI berbantuan media audio visual. 2) Disarankan kepada guru dapat lebih berinovasi dalam pembelajaran dengan menerapkan model pembelajaran $A T I$ dan didukung media pembelajaran untuk dapat meningkatkan hasil belajar siswa dan untuk meningkatkan kemampuan profesional guru mengelola pembelajaran. 3) Disarankan kepada Kepala sekolah, diharapkan dapat mengambil kebijakan untuk menerapkan model $A T I$ berbantuan media audio visual pada mata pelajaran ataupun jenjang pendidikan yang berbeda dan disesuaikan dengan kurikulum yang diterapkan di sekolah. 4) Kepada peneliti lain yang berminat untuk mengadakan penelitian lebih lanjut tentang model $A T I$ berbantuan media audio visual dalam bidang ilmu IPA maupun bidang ilmu lainnya yang sesuai, agar memperhatikan kendala-kendala yang dialami dalam penelitian ini sebagai bahan pertimbangan untuk perbaikan dan penyempurnaan penelitian yang akan dilaksanakan.

\section{Daftar Pustaka}

BSNP. 2006. Panduan Penyusunan Kurikulum Tingkat Satuan Pendidikan Jenjang Pendidikan Dasar dan Menengah. Jakarta: Pusat Kurikulum.

Daryanto. 2016. Media Pembelajaran. Yogyakarta: Penerbit Gava Media.

Daryanto. 2016. Media Pembelajaran. Yogyakarta: Penerbit Gava Media. 
Jayanto, Dw. Nym. R. Dwi. 2013. "Pengaruh Pembelajaran ATI (Aptitude Treatment Interaction) Terhadap Hasil Belajar IPA Siswa Kelas IV Semester II di SD Kelurahan Banyuning". Tersedia pada: https://ejournal.undiksha.ac.id/index.php/JJPGSD/article/view/1453/1314 (diakses pada: 3 Januari 2018)

Partimi, Ni Pt Irma. 2013. "Pengaruh Metode Bermain Peran Berbantuan Media Audio Visual Terhadap Hasil Belajar IPS Siswa Kelas IV SDN 1 Seririt". Tersedia pada: https://ejournal.undiksha.ac.id/index.php/JJPGSD/article/view/821/694 (dikses pada: 23 April 2018)

Putra, A.A. Ngurah Mahendra. 2013. "Pengaruh Model Pembelajaran ATI (Aptitude Treatment Interaction) Berbantuan Peta Konsep Terhadap Hasil Belajar IPA". Tersedia pada: https://ejournal.undiksha.ac.id/index.php (diakses pada: 3 Januari 2018)

Sisdiknas. 2006. Undang-Undang Republik Indonesia Nomor 20 Tahun 2003 SISDIKNAS Sistem Pendidikan Nasional. Bandung: Fokusmedia.

Sulastriningsih, Pt. 2012. "Pengaruh Model Process Oriented Guided Inquiry Learning Terhadap Kemampuan Pemahaman Konsep IPA Siswa Kelas V SD Gugus XI Kecamatan Buleleng". Tersedia pada: https://ejournal.undiksha.ac.id/index.php/JJPGSD/article/viewFile/820/693 (diakses pada: 2 Januari 2018).

Suryanata, I Gd. 2013. "Pengaruh Model Pembelajaran Synectics Berbantuan Media Audio Visual Terhadap Hasil Belajar IPS Kelas V Sd Gugus li Kecamatan Karangasem". Tersedia pada: https://ejournal.undiksha.ac.id/index.php/JJPGSD/article/view/1049/914 (diakses pada: 23 April 2018).

Trianto. 2012. Model Pembelajaran Terpadu. Jakarta: Prestasi Pustaka Publisher.

Widyastuthi, Ni Luh Oktalia. 2013. "Pengaruh Model Pembelajaran ATI (Aptitude Treatment Interaction) Terhadap Hasil Belajar IPA Kelas V SD Negeri 1 Melaya". Tersedia pada: https://ejournal.undiksha.ac.id/index.php/J JPGSD/article/view/829/702 (diakses pada: 3 Januari 2018). 